\title{
Molecular and Genetic Characterization of Ferrochelatase
}

\author{
Shigeru Taketani \\ Department of Hygiene, Kansai Medical University, \\ Moriguchi, Osaka $5 \% 0$
}

\section{INTRODUCTION}

Heme plays a role in the prosthetic group of a variety of hemoproteins and is an essential constituent of living cells. Heme consists of protoporphyrin IX and iron, of which iron is active as two transient states: ferrous and ferric ions. Iron has a high affinity with oxygen and can be reversibly oxidized by the transfer of a single electron to and from its environment. Thus, hemoproteins including hemoglobin, myoglobin, mitochondrial cytochromes, $b, c_{1}, c$, a and $a_{3}$, cytochromes $b_{5}$ and P-450 serve to transport and store oxygen.

Heme biosynthesis is a mitochondrial and cytoplasmic process in eukaryotic cells. The first step, condensation of succinyl-CoA with glycine to form 5aminolevulinic acid (ALA), takes place in mitochondria: this reaction is catalyzed by ALA synthase. Two molecules of ALA are combined to form porphobilinogen (PBG), which is a monopyrrole, and four molecules of $\mathrm{PBG}$ are then combined to form uroporphyrinogen, a cyclic tetrapyrrole. Then uroporphyrinogen is converted to coproporphyrinogen. These four steps from ALA to. coproporphyrinogen are cytoplasmic events. The three terminal steps from coproporphyrinogen to protoporphyrinogen, protoporphyrin, and then to protoheme are again mitochondrial processes.

The last step in heme biosynthesis is the insertion of a ferrous ion into protoporphyrin to produce protoheme IX (Fig. 1). This step is eatalyzed by the enzyme ferrochelatase (protoheme ferrolyase (EC 4.9.99.11)). This enzyme activity was first demonstrated in extracts of chicken erythrocytes by Goldberg et al. (1956). This activity was subsequently found in a variety of tissues, including liver (Porra and Jones 1963), plants (Jones 1968) and microorganisms (Porra and Ross 1965). The eukaryotic enzyme is located in the inner membrane of the mitochondrion and the active site of the enzyme faces the matrix side of the membrane (Jones and Jones 1969). Heme produced in mitochondria is exported to the cytoplasm and endoplasmic reticulum, where it is associated with apohemoproteins (Taketani and Tokunaga 1980; Senjo et al. 1985). It is known that

Revision accepted for publication July 20, 1993. 


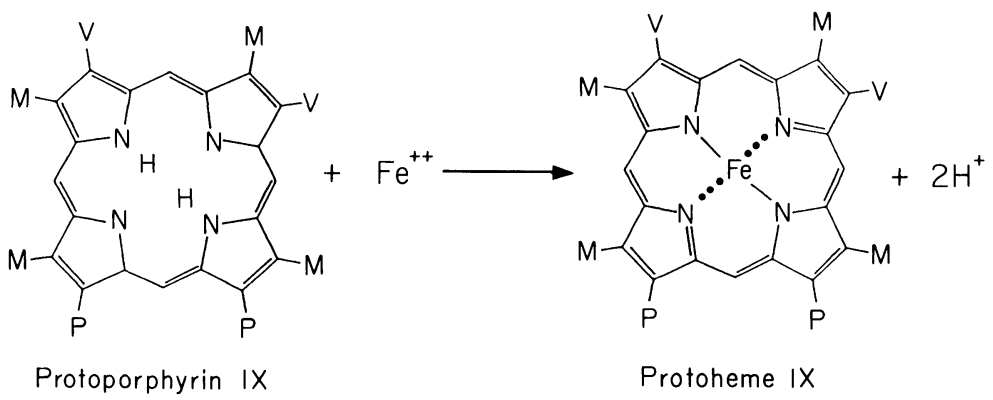

Fig. 1. Reaction of ferrochelatase. $\mathrm{M}$, methyl $\left(-\mathrm{CH}_{3}\right) ; \mathrm{P}$, propionate $\left(-\mathrm{CH}_{2} \mathrm{CH}_{2} \mathrm{COOH}\right) ; \mathrm{V}$, vinyl $\left(-\mathrm{CH}=\mathrm{CH}_{2}\right)$.

the insertion of ferrous ion into porphyrin occurs with an excess of ferrous ion (Falk 1964) and that this non-enzymatic reaction also proceeds under physiological conditions (Tokunaga and Sano 1972; Kassner and Walchak 1973). Whether the non-enzymatic reaction may in part contribute to heme synthesis in living cells is controversial. Yeast and bacterial heme auxotrophs, which lack ferrochelatase activity, lead to the conclusion that ferrochelatase acts as the key to heme production in biological systems (Dailey and Lascelles 1974). Here, I will describe recent advances in ferrochelatase research and discuss the significant function of the enzyme in the regulation of heme synthesis.

\section{Purification}

Many investigators have tried to purify ferrochelatase from various cells such as mammalian liver, chicken erythrocytes, plant tissues and bacteria. However, purification of the enzyme to achieve homogeneity had been obstructed until the advent of affinity chromatography. The principal obstacles to purification had been instability of the enzyme preparation (Mazanowska et al. 1969; Dailey 1977) and the tendency of the enzyme to form intractable aggregates (Yoneyama et al. 1965; Mazanowska et al. 1969). Mailer et al. (1980) reported on the purification of rat liver ferrochelatase with a molecular weight of 63,000 daltons (Da), using a porphyrin affinity column. We had tried purification with several commercially available affinity chromatographies as well as porphyrin-bound chromatography without success until the instability of the enzyme was overcome by the addition of $20 \%$ glycerol and $1 \mathrm{mM}$ dithiothreitol. Then, for the first time, we obtained reproducible results for the purification by the use of a Blue-dye column (Taketani and Tokunaga 1981). The enzyme can bind strongly to Cibacron-blue dye by hydrophobic interaction even in the presence of high concentrations of salt ( $2 \mathrm{M}$ $\mathrm{NaCl}$ ) and non-ionic detergents. The elution of the enzyme from the dye was carried out with ionic detergents and high concentrations of salt ( $>0.5 \mathrm{M} \mathrm{NaCl}$ ). But the enzyme did not bind to Red dye-, phospholipid- or porphyrin-bound beads (Taketani, unpublished). In addition, Camadro and Labbe (1988) reported 
that the yeast enzyme was significantly activated by palmitic acid. They then tried to purify the yeast enzyme by palmitic acid-bound affinity chromatography, but the enzyme did not bind to the column. To date, the mechanism behind the binding of the enzyme to the blue dye remains unclear. The molecular weight of the purified rat ferrochelatase was found to be 42,500 Da (Taketani and Tokunaga 1981). Subsequently, by using similar techniques, the enzyme was purified from bovine (Taketai and Tokunaga 1982; Dailey and Fleming 1983), mouse (Dailey et al. 1986) and human livers (Mathews-Roth et al. 1987), chicken erythrocytes (Hanson and Dailey 1984), yeast (Camadro and Labbe 1988) and photosynthetic bacteria (Dailey 1982). The enzymes of all species showed a molecular mass of 40-42 kilodaltons ( $\mathrm{kDa}$ ), except that of photosynthetic bacteria (Mr. 115,000).

\section{Substrate specificity}

The native porphyrin substrate for the enzyme is protoporphyrin IX, but the reaction proceeds with a variety of IX isomers, such as mesoporphyrin, deuteroporphyrin and hematoporphyrin. Free dicarboxylate porphyrins are suitable substrates, but not esterified or protein-bound ones (Honeyborne et al. 1979; Taketani and Tokunaga 1982). It is noted that, of all dicarboxylate porphyrins, the incorporation of ferrous ion into protoporphyrin is the least reactive in vitro. Living organisms can utilize such a low-reactive porphyrin as protoporphyrin to produce heme, which may essentially regulate heme synthesis. The various investigators' data on $\mathrm{Km}$ values for the substrates varies. One explanation for the observed variability is the difference in the source of the enzyme. Another explanation is the difference in enzyme assay conditions: One investigator uses a Thunberg tube to create vaccum conditions, another uses dithiothreitol or ascorbate to maintain reduced iron, or the assays are sometimes carried out under aerobic conditions; also iron or zinc is used as the metal substrates. Thus, the enzyme assay is quite complicated and each researcher utilizes different conditions.

Divalent metal ions including $\mathrm{Co}^{2+}, \mathrm{Zn}^{2+}$ and $\mathrm{Fe}^{2+}$ can be incorporated into porphyrin rings to form corresponding metalloporphyrins while $\mathrm{Ni}^{2+}$ is a poor substrate for the enzyme (Taketani and Tokunaga 1982). Of the divalent metal ions tested, $\mathrm{Cu}^{2+}, \mathrm{Mn}^{2+}$ or $\mathrm{Mg}^{2+}$ cannot be substrates, inhibiting enzyme activity to differing extents (Taketani and Tokunaga 1981; Dailey and Fleming 1983). Heavy metals, which interact with sulfhydryl groups, can interfere with the sulfhydryl groups of the enzyme involved in the catalytic reaction. Under some abnormal conditions, cells can still make metalloporphyrins. Camadro and Labbe (1982) reported that an accumulation of $\mathrm{Zn}$-protoporphyrin is observed in yeast grown in medium supplemented with $\mathrm{ZnCl}_{2}$. But $\mathrm{Zn}$-protoporphyrin is not detected in a ferrochelatase-deficient yeast mutant cultured with $\mathrm{ZnCl}_{2}$. When $\mathrm{CoCl}_{2}$ is injected into a rat, an accumulation of Co-protoporphyrin in the liver is observed (Igarashi et al. 1978; Sinclair et al. 1982). Futhermore, accumulation of 
Zn-protoporphyrin is observed in lead-poisoned workers and animals (Lamolla and Yamane 1974). Lead disturbs the environment of the ferrochelatase molecule, or inhibits ferrochelatase activity in addition to iron-reducing activity, leading to the hypothesis that $\mathrm{Zn}^{2+}$ can easily reach the active site of ferrochelatase (Taketani et al. 1986). Finally, immuno-inhibition experiments using antibody against the purified ferrochelatase demonstrate that iron-, zinc- and cobalt-chelatase activities are inhibited by the antibody, thereby confirming the theory that syntheses of iron-, zinc- and cobalt-porphyrin can be ascribed to ferrochelatase (Taketani and Tokunaga 1982).

\section{Kinetics of the enzyme reaction}

The kinetics of the enzyme can be investigated using various substrates and inhibitors. The reaction requires two substrates, porphyrin and metal ion, producing metalloporphyrin and two protons. Dailey and Fleming (1983) proposed that the catalytic reaction of ferrochelatase exhibits an ordered bi-bi mechanism. Namely, the enzyme initially binds ferrous ion with the concomitant release of two protons, followed by binding of porphyrin. Insertion of iron into the porphyrin ring with an exchange of the two pyrrolic nitrogen protons into the enzyme displaces the ferrous ion chelate. On the other hand, using membrane-bound ferrochelatase, Camadro et al. (1985) and Rossi et al. (1990) proposed that the enzyme reaction occurs by a random bi-bi mechanism in which each substrate binds randomly to the enzyme, since the apparent Michaelis constant $(\mathrm{Km})$ for each substrate varied with the concentration of the second substrate. Details of these differences are unclear, but it is possible that these differences may be due to the difference in the metal ions used as substrates, since the latter experiment utilizes Zn-porphyrin formation and the former, Feporphyrin formation.

\section{Reaction mechanism of the enzyme}

Sulfhydryl reagents such as iodoacetamide and N-ethylmaleimide inactivate the enzyme, concomitant with blocking the binding of ferrous ion to the active site (Dailey 1984). Conversely, ferrous ion has a protective effect against inactivation by thiol reagents. It is very interesting that other metal ions have a protective effect against thiol reagents, but studies have not yet been performed with the enzyme. On the other hand, porphyrins do not protect from the inactivation by sulfhydryl reagents. Pseudo-first-order inactivation by sulfhydryl reagents might account for the hypothesis that one -SH group of the enzyme is sufficient to inhibit the binding of iron, while two - $\mathrm{SH}$ groups are involved in the chelate reaction. Since the number and position of the porphyrin propionate groups are critical for catalysis, there is the possibility of charge pair interaction between the anionic propionate and cationic protein. Dailey and Fleming (1986) examined this possibility by chemically modifying the enzyme, finding that the arginyl- 
residue is essential for the reaction by changing the $\mathrm{Km}$ for porphyrin. The above chemical modifications revealed the amino acid residue binds to both substrates, but the reaction mechanism of the enzyme is not fully elucidated. On the basis of the planar and non-polar structure of porphyrin, hydrophobic interaction between the active site of the enzyme and porphyrin must be involved. In this regard, the enzyme is markedly activated by lipids (Sawada et al. 1969; Simpson and Poulson 1977). Among the lipids tested, free fatty acids activate the purified rat enzyme more than do phospholipids (Taketani and Tokunaga 1981). Camadro and Labbe (1988) found that free fatty acids are essential for the enzyme assay during the purification of yeast ferrochelatase. Using the crude enzyme of human lymphocytes, the addition of fatty acids to the assay leads to marked activation and reproducible activity of ferrochelatase (Rossi et al. 1988). The purified enzyme from bovine liver is slightly activated by fatty acids as well as phospholipids, including phosphatidylcholine and cardiolipin (Taketani and Tokunaga 1982; Dailey and Fleming 1983). As for the role of lipids in enzyme activity, it is proposed that the anionic charge on the phosphate group of phospholipids and the carboxyl group of fatty acids serve to bind iron and bring it near the active site, or alternatively, that lipids help to dissolve the porphyrin and place it into the active site. Surprisingly, the non-enzymatic reaction proceeds easily at $37^{\circ} \mathrm{C}$ in the presence of unsaturated fatty acids, but not phospholipids (Taketani and Tokunaga 1984). Using zinc and cobalt ions, the non-enzymatic reaction occurrs under similar conditions. The addition of detergents completely inhibits the non-enzymatic reaction, but not the enzymatic reaction (Taketani and Tokunaga 1984). Taking the above observations into consideration, it is possible that the presence of fatty acids facilitates the insertion of the metal ion into porphyrin, or that fatty acids make some environments similar to that of the active portion of ferrochelatase.

It should be pointed out that $\mathrm{N}$-alkylprotoporphyrin is a potent inhibitor of ferrochelatase (Dailey and Fleming 1983; De Matteis et al. 1985). Nalkylprotoporphyrin is a metabolite of the heme-moiety. of cytochrome P-450 when animals are administered 3.5-diethoxycarbonyl-1, 4-dihydro-2, 4, 6trimethyl-pyridine (DDC) or griseofulvin (Marks et al. 1985; Oritz de Montellano et al. 1986; De Matteis et al. 1987). The inhibition of ferrochelatase by Nalkylprotoporphyrin has been shown to be via tight-binding competitive inhibition. Although a number of studies using various $\mathrm{N}$-alkylporphyrin isomers have been done, a definitive model for the enzyme inhibition has not been conclusively determined since the degree of the inhibition varies depending on the structure of the isomers (Oritz de Montellano et al. 1981). The determination of the active site of the enzyme will resolve the nature of the inhibition mechanism of $\mathrm{N}$ alkylprotoporphyrin. The main obstacle for clarifying the reaction mechanism and the active site of the ferrochelatase is the fact that the enzyme can be purified from various tissues only in small amounts. When large amounts of the enzyme 
are obtained from transfected cells (i.e. Baculovirus system) expressing recombinant ferrochelatase, it will become possible to clarify data.

\section{Location of ferrochelatase in mitochondria}

Ferrous ion is an absolute requirement for ferrochelatase in the biological system. Reduction of ferric ion is indispensable to heme synthesis. Accordingly, some mechanism to maintain this reduced form must exist in mitochondria, or the reduction of ferric ion must occur near ferrochelatase molecule since ferrous ion is unstable.

Barnes et al. (1973) have reported that mitochondrial succinate and NADH oxidations may serve to reduce iron. To test this possibility, subfractionation of bovine heart mitochondria, a well characterized fraction rich in electron transport system reactions was performed. During the fractionation of the mitochondria, ferrochelatase was co-purified with Complex I (Taketani et al. 1986). No ferrochelatase activity was found in Complexes II, III and IV. The presence of $\mathrm{NADH}$ led to ferric ion-dependent heme synthesis in Complex I. Thus, NADH dehydrogenase must have been involved in the reduction of ferric ion and association with ferrochelatase. Camadro and Labbe (1988) have reported that more than 10 peptides containing ferrochelatase were found, utilizing anti-yeast ferrochelatase antibodies, in immunoprecipitates from yeast metabolically labeled with radioactive methionine. This supported the hypothesis that ferrochelatase could be associated with the proteins of the yeast respiratory chain. Recently, the main $42 \mathrm{kDa}$ protein associated with Complex I was cloned (Fearnley et al. 1991). The $42 \mathrm{kDa}$ protein was found to be encoded by nuclear mRNA, but the amino acid sequence deduced from cDNA encoding the $42 \mathrm{kDa}$ protein was different from that of ferrochelatase. Although the location of ferrochelatase seemed to be related to that of $\mathrm{NADH}$ dehydrogenase, details of the joining of iron metabolism and heme synthesis are still unclear. This remains as one of the most interesting subjects for future research on cellular control of heme synthesis.

\section{Isolation and sequence analysis of ferrochelatase $\mathrm{cDNA}$}

Mouse erythroleukemia (MEL) cells can be induced to undergo erythroid differentiation by treatment with various compounds including dimethylsulfoxide (DMSO) and hemin (Friend et al. 1971; Granick and Sassa 1978). In MEL cells induced with DMSO enzyme activities of the heme biosynthetic pathway and hemoglobin biosynthesis increased (Friend et al. 1971; Sassa 1976). Studies with MEL cells have resulted in many ideas concerning erythroid differentiation. During differentiation, induction of ferrochelatase was observed; when the cells were treated with $2 \%$ DMSO, the activity and the quantity of the enzyme increased as much as 5-fold in a parallel fashion (Beamount et al. 1984; Nakahashi et al. 1990a). Under these conditions, the amounts of ferrochelatase translated in vitro at the direction of RNA isolated from control and DMSO-treated cells were 
examined (Karr and Dailey 1988). However, enzyme synthesis from RNA of DMSO-treated cells was not detected, while a $42 \mathrm{kDa}$ polypeptide immunoprecipitated by anti-ferrochelatase antibody was synthesized from control RNA. The $42 \mathrm{kDa}$ polypeptide was found to be a precursor of the mitochondrial mature protein, since the $42 \mathrm{kDa}$ protein was translocated into mitochondria where the protein was converted to a $42 \mathrm{kDa}$ protein. In any event, it remained unclear whether in vitro synthesis of the enzyme with mRNA from the DMSO-treated MEL cells was undetectable. As a result of this report, questions arose as to whether the copy number of the ferrochelatase in MEL cells was increased by DMSO treatment, or post-transcriptional regulation of the enzyme expression occurred.

Observations that mRNAs encoding other enzymes of the heme biosynthetic pathway, such as the erythroid type of ALA synthase (Schoenhaut and Curtis 1986) and PBG deaminase (Grandchamp et al. 1985) increased with the treatment of MEL cells with DMSO, suggested that the level of transcript of ferrochelatase in DMSO-treated MEL cells could have been increased. Subsequently, a cDNA library of mRNA from MEL cells treated with $2 \%$ DMSO for $72 \mathrm{~h}$ was constructed. Using anti-bovine ferrochelatase antibody which cross-reacts with mouse ferrochelatase, immuno-screening of this $\lambda$ GT11 library was carried out. From $10^{5}$ independent phage plaques, one positive clone was isolated (Taketani et al. 1990). The isolated cDNA contained several carboxy-terminal amino acid residues and a 3 -noncoding region. Subsequent plaque hybridization with the obtained insert resulted in the isolation of full-length clones (2.2 and 2.9 kilobases $(\mathrm{kb})$ ). The cDNA of mouse ferrochelatase contains two polyadenylation sites, thus two mRNAs were isolated. Both mRNAs contains the same protein coding region for ferrochelatase. The amino acid sequence deduced from the isolated clones showed that the precursor contains 420 amino acids and has a calculated molecular weight of 47,130 Da. Based on the amino acid sequence determined for the amino-terminus of the purified mouse enzyme, the mature protein contains 367 amino acids and is proceded by a leader peptide of 53 amino acids. The molecular weight of the mature protein, 41,692 Da, was consistent with that of purified mouse ferrochelatase (Mr. 41,000). Brenner and Fraiser (1991) also isolated a cDNA clone from the MEL cell cDNA library, using probe hybridization. The sequence of their cDNA clone was quite similar to the sequence described above, except that one of the isolated cDNA clones had a different 3 '-noncoding region. The explanation for this difference is unclear.

The yeast ferrochelatase gene was isolated by functional complementation of ferrochelatase-deficient mutants (Labbe-Bois 1990). Sequence analysis of the isolated gene revealed an open reading frame of 1179 base pairs (bp) encoding a precursor form of the protein containing a 31 amino acid leader peptide. The mature enzyme has been shown to contain 362 amino acid residues. The calculated molecular weight was $40,900 \mathrm{Da}$, which was consistent with the molecular 
weight of the purified yeast ferrochelatase. RNA blot analysis showed that the gene encoded a $1.4 \mathrm{~kb}$ mRNA, which was slightly suppressed by glucose repression.

cDNA cloning of mouse ferrochelatase has facilitated the isolation of homologous cDNA from human mRNA (Nakahashi et al. 1990b). The cDNA from human placental mRNA exhibited a high degree of sequence identity with MEL cell ferrochelatase cDNA. Although the amino-terminal sequence analysis of the purified human ferrochelatase failed, a comparison of the amino-terminal sequence of the bovine and mouse enzymes suggested that the preprotein consisted of a presequence containing 54 amino acids, followed by 369 amino acids of the mature protein. The molecular weight calculated from the deduced amino acid composition was $47,833 \mathrm{Da}$ for the preprotein and 42,158 $\mathrm{Da}$ for the mature ferrochelatase. The amino acid identities of human enzyme to mouse and yeast enzymes were $88 \%$ and $46 \%$, respectively (Fig. 2). Amino acid sequence comparison between mammalian and yeast enzymes revealed the carboxyl-terminal half of the mature peptide to be highly conserved. Hydropathy profiles derived from amino acid sequences of three species have led to the hypothesis that the enzyme does not contain the mitochondrial membrane-spanning hydrophobic region, although the enzyme was found to be a membrane protein (Fig. 3). Since

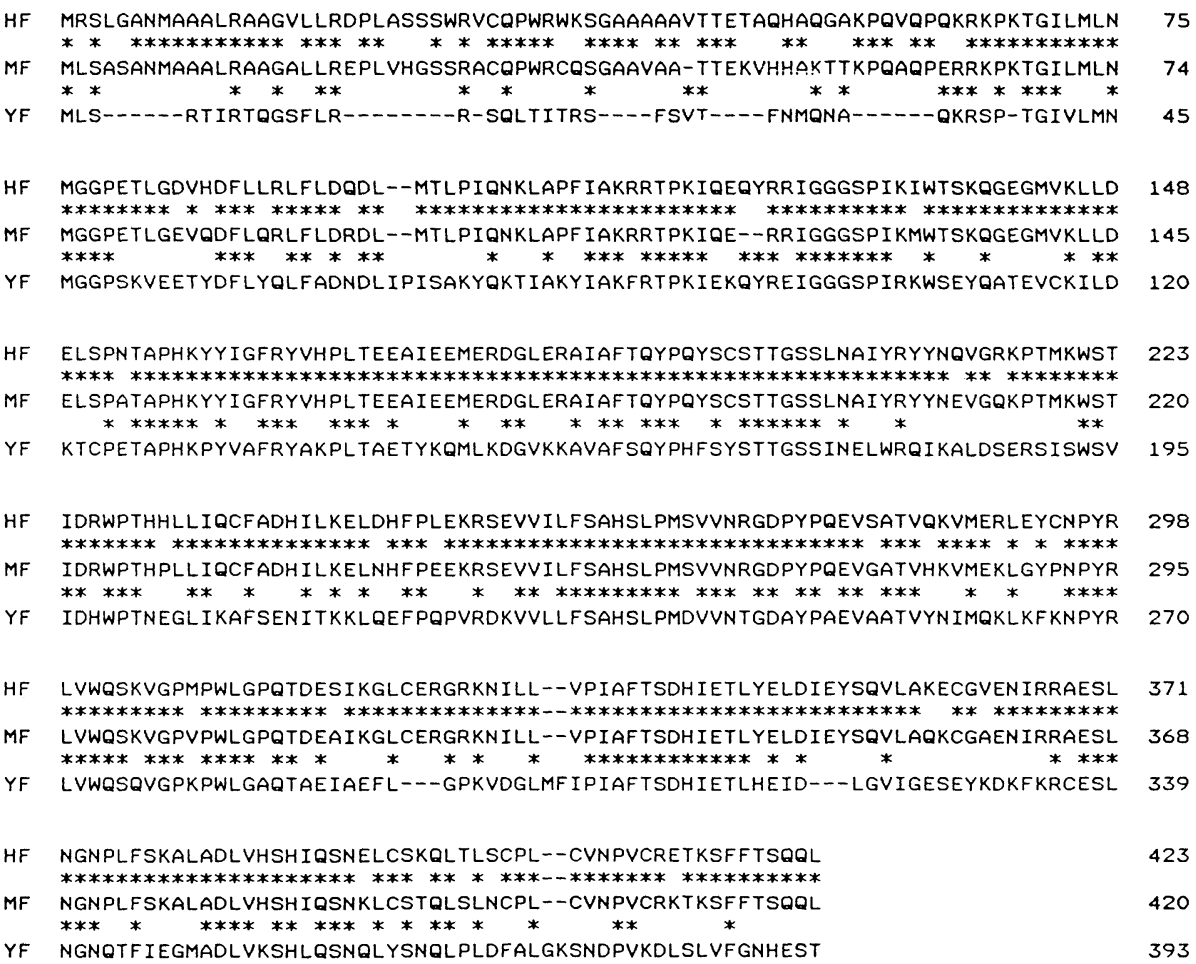

Fig. 2. Homolgy in the deduced amino acid sequences of human, mouse and yeast ferrochelatases. HF, human; MF, mouse; YF, yeast ferrochelatase. 


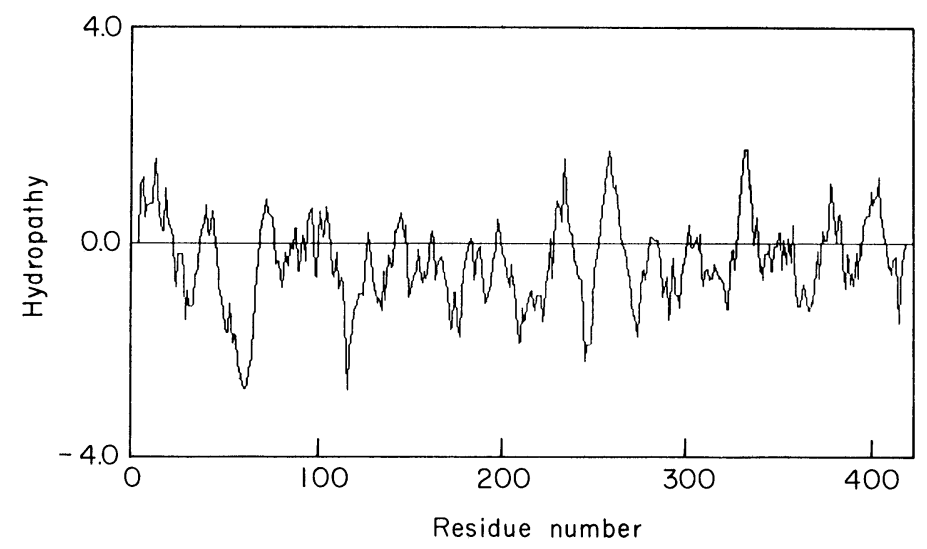

Fig. 3. Hydropathy profile of mouse ferrochelatase. Hydropathy was analysed by DNA-strider program using a window size of 11 amino acids.

lipophilic protoporphyrin was produced in the inner membrane of mitochodria by the penultimate enzyme, protoporphyrinogen oxidase which may interact with ferrochelatase in the membrane (Ferreira et al. 1988), some hydrophobic regions of the enzyme may be involved in the catalytic reaction. Dailey and Fleming (1986) have postulated, by chemical modification experiments, that the arginine residue of the enzyme could be a binding site of porphyrin. The binding site of iron was postulated to be the sulfhydryl group of the enzyme. At the present time, it is difficult to define the portion of the active site of the enzyme from the deduced amino acid sequences. Studies of site mutagenesis of the cloned ferrochelatase and the mutation site of the enzyme in erythropoietic protoporphyria (EPP) will clarify the active site involved in the enzyme reaction.

Gene for Escherichia coli ferrochelatase was characterized, and the open reading frame encoded 320 amino acid residues (Miyamoto et al. 1991). Deduced amino acid sequence of the bacterial enzyme shows $26-28 \%$ identities to those of the mammalian enzymes. Conserved regions between bacterial and mammalian enzymes will help to elucidate the mechanism of the catalytic reaction. Otherwise, the bacterial enzyme was found in the soluble fraction, suggesting that ferrochelatase may exist originally as a soluble form.

\section{Gene structure and expression}

Human placental ferrochelatase mRNA is encoded by a single nuclear gene which spans approximately $45 \mathrm{~kb}$ of chromosomal DNA. Isolation of the ferrochelatase gene shows the location to be chromosome 18q21.3 (Brenner et al. 1992; Taketani et al. 1992). No biotin-labeled segment of the human ferrochelatse gene is detected in other regions of the chromosomes, confirming that ferrochelatase is encoded by a single gene. Whitcome et al. (1991) reported similar results, determining the location of the ferrochelatase gene as chromosome 18q 22. This 
location of the ferrochelatase gene in chromosome 18 differs from those of any other genes of the heme biosynthetic pathway enzymes: erythroid-type ALA synthase, chromosome x (Cox et al. 1990); non-erythroid-type ALA synthase, chromosome 3 (Bishop et al. 1990); ALA dehydratase, chromosome 9 (Eiberg et al. 1983); PBG deaminase, chromosome 11 (Meisler et al. 1980); uroporphyrinogen decarboxylase, chromosome 1 (de Verneuil et al. 1984); and coproporphyrinogen oxidase, chromosome 9 (Grandchamp et al. 1983). The human ferrochelatase gene consists of 11 exons which range in size from 108 to $1293 \mathrm{bp}$. The results of Northern blot hybridization indicate that the gene encodes two mRNAs of 2.5 and $1.6 \mathrm{~kb}$ which are present in all cells including human leukemia HL60 cells, K562 cells, hepatoma HepG2 cells and Epstein-Barr virus-transformed lymphoblastoid B cells (Nakahashi et al. 1990b; Nakahashi et al. 1992). The two bands of human ferrochelatase mRNA are attributed to two polyadenylation sites (Nakahashi et al. 1990b). This is similar to the transcript of the mouse ferrochelatase gene which appears as a 2.2 and $2.9 \mathrm{~kb} \mathrm{mRNA}$. When MEL cells are induced to differentiate with DMSO, the amounts of ferrochelatase mRNA increase 5- to 6-fold by $72 \mathrm{hr}$, and the size of the mRNA in the differentiated MEL cells is the same as that in mouse liver (Taketani et al. 1990). Northern blot analysis of rat ferrochelatase mRNA reveals that the ferrochelatase mRNA in liver is shown to be a single 2.4 $\mathrm{kb}$ band, and that the amount of an mRNA of the same size markedly increases in the spleen of anemic rats (Taketani, unpublished data). By all available criteria, the structure of the transcript of ferrochelatase in erythroid cells appears to be identical to that found in liver. Primer extension analysis indicates that ferrochelatase mRNA in human erythroleukemia K562 cells has the same $5^{\prime}$ terminus as that in human hepatoma HepG2 cells (Taketani et al. 1992). The size of the MEL cell enzyme, as determined by sodium dodecylsulfate-polyacrylamide gel electrophoresis, appears to be identical to that of mouse liver (Nakahashi et al. 1990a). In addition, peptide mapping of the enzyme from liver as well as that from MEL cells treated with DMSO, shows identical digestion peptides, suggesting that only one type of ferrochelatase is expressed in erythroid and non-erythroid tissues (Nakahashi et al. 1990a). Thus, the regulation of ferrochelatase enzyme expression is different from the mechanism by which tissue-specific expression of PBG deaminase is controlled, which utilizes $5^{\prime}$-alternative splicing of an erythroid specific promoter situated $3^{\prime}$ to the house-keeping promoter (Chretien et al. 1988). The 5'-flanking sequence of the human ferrochelatase gene reveals that it does not contain the CAAT or TATA box but the GC box, indicating that the gene is responsible for the maintenance of normal house-keeping functions. Taking these observations together with the structure of the gene, mRNA and protein, this gene is found to be active in all animal cells. The 5'-promoter region of the human ferrochelatase gene contains a possible GATA-1 binding site at position - 321 to -316 (ATATCT), in the opposite orientation, which conforms with 5 out of 6 bases to the consensus sequence (WGATAR: $\mathrm{W}=\mathrm{A} / \mathrm{T}$ and $\mathrm{R}=\mathrm{A} / \mathrm{G}$ ) (Taketani et 
al. 1992). This DNA motif serves in part as a signature for erythroid-specific gene expression and is present in the promoters of globin (Orkin 1990), erythroid-type ALA synthase (Cox et al. 1991) and PBG deaminase genes (Mignotte et al. 1989a). The sequence TGAGTCA, which is the consensus sequence of the NF-E2 binding site, is found at position -277 to -271 (Taketani et al. 1992). The NF-E2 motif was first demonstrated in the erythroid-type PBG deaminase promoter (Mignotte et al. 1989a) and more recently, multiple sites have been found in the upstream enhancer of the beta-globin gene (Philipson et al. 1990). The NF-E2 sequence in the ferrochelatase gene is identical to those observed in human erythroid ALA synthase (Cox et al. 1991) and PBG deaminase promoters (Mignotte et al. 1989b). A gel retardation assay shows that specific proteins in nuclear extracts of MEL cells bind to the $-381 /-261$ segment of $5^{\prime}$-promoter region of the ferrochelatase gene (Fig. 4). One band is diminished by excess probe containing the GATA-1 binding site $(-329 /-307)$, suggesting that GATA-1 may regulate the transcription of the ferrochelatase gene. The other band is diminished by excess probe containing the NF-E2 binding site $(-289 /-264)$. These results suggest that NF-E2 co-functions with GATA-1 to play a role in the induction of ferrochelatase

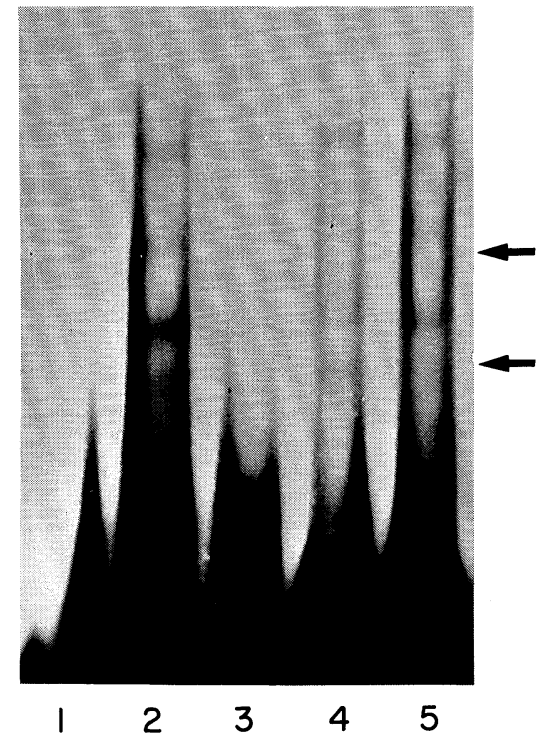

Fig. 4. Gel-retardation assay of protein-DNA interaction in the ferrochelatase gene enhancer region. Assay using the $-381 /-261$ gene segment of ferrochelatase was mixed without (lane 1 ) or with $2 \mu \mathrm{g}$ of nuclear extracts of MEL cells (lanes 2-5). The $-381 /-261$ segment (lane 3), double-stranded $-329 /-307$ probe containing GATA-1 binding site (lane 4) and the -289 / -264 probe containing NF-E2 binding site (lane 5) were added at 100-fold excess as competitors. The DNA-protein complex was separated by $4 \%$ polyacrylamide gel electrophoresis. The arrows indicate the positions of specific bindings. 
during erythroid differentiation.

\section{Regulation of ferrochelatase synthesis during erythroid differentiation}

Regulation of heme biosynthesis is different in hepatic (non-erythroid) and erythroid tissues. In non-erythroid cells, the rate of heme synthesis is controlled by the first pathway enzyme, ALA synthase, at transcriptional and posttranscriptional levels (Yamauchi et al. 1980; Yamamoto et al. 1982, 1983, 1988). In differentiating erythroid cells, ALA synthase is not present in the same regulatory mechanism, and a diferent type of ALA synthase is present (Yamamoto et al. 1985; Riddle et al. 1989). Differentiation occurs after ferrochelatase is induced, even though the other enzymes of the heme biosynthetic pathway are induced earlier (Sassa 1976). Mutationally or chemically-induced blockage of ferrochelatase arrests the differentiation (Rutherford et al. 1979; Fadigan and Dailey 1987). Thus, it has been considered that ferrochelatase activity could limit the rate of differentiation of erythroid cells. Analysis of the ferrochelatase gene shows that the gene is present in single copy in the genome and that one type of transcript is produced in erythroid and non-erythroid cells. As described before, primer extention analysis reveals that $5^{\prime}$-alternative splicing, which occurrs in the transcript of the PBG deaminase gene, is not observed in the ferrochelatase gene. The $5^{\prime}$-flanking region of the human ferrochelatase gene has binding sites for GATA-1 and NF-E2, and both erythroid-specific transcriptional factors may regulate the induction of ferrochelatase during erythroid differentiation. An increase of ferrochelatase mRNA in MEL cells is observed within $12 \mathrm{~h}$ after the addition of DMSO, and parallells that of erythroid ALA synthase (Fukuda et al. 1993). These inductions are earlier than those of mRNAs encoding other heme biosynthetic enzymes (Grandchamp et al. 1985; Fujita et al. 1991b). The findings suggest that an increase in the expression of ferrochelatase may be one of the important events in erythroid differentiation. The amount and activity of ferrochelatase in MEL cells increases within $24 \mathrm{hr}$ after the addition of DMSO, and gradually continues to increase thereafter (Beamount et al. 1984; Nakahashi et al. 1990a).

In an early study on the induction of ferrochelatase activity, ${ }^{59} \mathrm{Fe}$-heme formation from exogeneously-supplied radioactive iron was measured for 4 days following the addition of DMSO (Sassa 1976). This method did not directly reflect enzyme activity. The increase in ${ }^{59} \mathrm{Fe}$-heme synthesis was in disagreement with data resulting from direct measurement of ferrochelatase activity. Considering that multiple steps, which include iron uptake into cells and mitochondria as well as reduction of ferric ion, are involved in the incorporation of exogenous iron into heme, the iron supply may be a rate-limiting step of heme synthesis during erythroid differentiation. Conder et al. (1991) recently reported that coproporphyrinogen oxidase may be rate-limiting on the induction of heme synthesis of MEL cells. If so, supply of the substrate for ferrochelatase would control the 
production of heme. Fujita et al. (1991a) very recently reported that DR1, a mutant of the MEL cell line which is not induced to differentiate with DMSO, did not induce erythroid-type ALA synthase production. Of the mRNAs for the heme synthetic enzymes tested, PBG deaminase, uroporphyrinogen decarboxylase and ferrochelatase were normally induced in DR1 cell by treatment with DMSO. The location of the mutation in DR1 cells has not been defined.

Based on the above observations, it seems unlikely that induction of ferrochelatase is the sole rate-limiting step of heme synthesis in MEL cells. Although the MEL cell is a useful model for the elucidation of erythroid differentiation, other cells including human-erythropoietin responsive cells (Sassa 1980) and bone marrow cells (Sassa and Urabe 1979; Beru and Goldwasser 1985) exhibit a different regulatory mechanism by which erythropoiesis may be under the control of the $\mathrm{PBG}$ level, suggesting that multiple factors are concerned with the regulation of heme synthesis in erythroid cells.

\section{Molecular basis of erythropoietic protoporphyria}

Erythropoietic protoporphyria (EPP) is an inherited disease derived from a decrease of ferrochelatase activity. EPP is characterized by the accumulation of protoporphyrin and by acute solar photosensitivity, established by Mangus et al. (1961) and Langhof et al. (1961). The disease is generally known to be inherited in an autosomal dominant characteristic with partial penetrance. In one patient, however, a homozygous mutant is reported (Deybach et al. 1986). Ferrochelatase deficiency is described in cattle (Ruth et al. 1978). Bovine protoporphyria differ from human EPP in that it is inherited in an autosomal recessive pattern (Bloomer et al. 1982). Biochemical studies demonstrate that the mutant shows 10 to $15 \%$ ferrochelatase activity of control level, although immunochemical experiments revealed that a normal size of ferrochelatase $(\sim 40 \mathrm{kDa})$ is present in normal levels (Bloomer et al. 1987). Very recently, a viable autosomal recessive mutation causing jaundice and anemia in mice arose by a mutagenesis experiment using ethylnitrosourea (Tutois et al. 1991). The mutant mice exhibits ferrochelatase activity at $2.7,6.3$ and $3.3 \%$ of normal levels in kidney, liver and spleen, respectively. Heterozygotes are not anemic and liver function is normal despite the fact that ferrochelatase activity is $45-65 \%$ of control. To date, no study on the molecular basis of animal protoporphyria has been carried out. Further studies of molecular genetics will clarify the molecular basis of protoporphyria in animals, and the difference in pathogenesis of protoporphyria among different species.

Isolation of the human ferrochelatase cDNA and gene can facilitate the demonstration of the molecular basis of EPP. Double mutation of a homozygous EPP patient, in which ferrochelatase activity was $6 \%$ of control, has been demonstrated (Lamoril et al. 1991). One allele was found to have a single mutation from $G$ to $T$ at nucleotide 163 , corresponding to a change from glycine to cysteine at amino acid residue 55. The second mutation was a $\mathrm{G}$ to $\mathrm{A}$ at 
nucleotide 801, changing methonine to isoleucine at amino acid residue 267 . The EPP patient, a young caucasian girl, was subsequently analyzed for ferrochelatase activity (Nakahashi et al. 1992). The patient shows half the ferrochelatase activity found in control subjects, as determined by immunoblot analysis. The concentration of ferrochelatase mRNA present in the patient was approximately half that of the control. The mRNA from this patient, as determined by the polymerase chain-reaction method, demonstrated that about one-tenth of the ferrochelatase mRNA lacked exon 2. Half of the genomic DNA of the patient was found to have a $\mathrm{C}$ to $\mathrm{T}$ mutation in intron 1, 23 base pairs upstream from the first base pair in exon 2. The rest of the DNA was the same as that of normal subjects. These results showed that the patient had a typical mode of EPP inheritance as an autosomal dominant trait. The mechanism by which normal splicing was prevent by the $\mathrm{C}$ to $\mathrm{T}$ mutation near the acceptor site of intron 1 of the EPP ferrochelatase gene remains unknown. Brenner et al. (1992) observed that a single point mutation in ferrochelatase cDNA of protoporphyria resulted in the conversion of a phenylalanine (TTC) to a serine (TCC) in the carboxy terminal end of the protein at 417. Expression of this mutated ferrochelatase led to a marked deficiency in the enzyme activity. Two Japanese EPP patients have been analyzed and the mutations of the ferrochelatase mRNAs were found to involve skipped exon 7 or 9, respectively (Nakahashi et al. 1993a, b). Half the ferrochelatase mRNA in both patients was normal. This can be accounted for by inheritance of the EPP as an autosomal dominant. Thus, all the analyzed mutations were found in different positions of the ferrochelatase gene. In the families of these patients, not all members containing an abnormal ferrochelatase gene acquire EPP. Multifactorial inheritance (i.e. HLA type) or environmental conditions may be a link in EPP. More information on the molecular defect of ferrochelatase in EPP is required to clarify the mechanism of the pathogenesis.

\section{Acknowledgments}

This work was supported by grants for Scientific Research from the Ministry of Education, Science, and Culture of Japan. I thank F. Shigenobu for assistance in preparing the manuscript, and I am grateful to Dr. H. Kohno for comments, and Drs. I. Tsukahara and R. Tokunaga for their encouragements.

\section{References}

1) Barnes, R., Connelly, J.L. \& Jones, O.T.G. (1973) The utilization of iron and its complex by mammalian mitochondria. Biochem. J., 128, 1043-1055.

2) Beamount, C., Deybach, J.C., Grandchamp, B., Da Silva, V., de Verneuil, H. \& Nordmann, Y. (1984) Effects of succinylacetone on dimethylsulfoxide-mediated induction of heme pathway enzymes in mouse Friend virus-transformed erythroleukemia cells. Exp. Cell Res., 154, 474-484.

3) Beru, N. \& Goldwasser, E. (1985) The regulation of heme biosynthesis during erythropoietin-induced erythroid differentiation. J. Biol. Chem., 260, 9251-9257.

4) Bishop, D.F., Henderson, A.S. \& Astrin, K.H. (1990) Human $\delta$-aminolevulinate 
synthase: Assignment of the housekeeping gene to $3 \mathrm{p} 21$ and the erythroid-specific gene to the x-chromosome. Genomics, 7, 207-214.

5) Bloomer, J.R., Morton, K.O., Reuter, R.J. \& Ruth, G.R. (1982) Bovine protoporphyria: Documentation of autosomal recessive inheritence and comparison with the human disease through measurement of heme synthase activity. Am. J. Hum. Genet., 34, 322-330.

6) Bloomer, J.R., Hill, H.D., Morton, K.O., Anderson-Burnham, L.A. \& Strake, J.G. (1987) The enzyme defect on bovine protoporphyria. Studies with purified ferrochelatase. J. Biol. Chem., 262, 667-671.

7) Brenner, D.A. \& Fraiser, F. (1991) Cloning of murine ferrochelatase. Proc. Natl. Acad. Sci. USA, 88, 349-853.

8) Brenner, D.A., Didier, J.M., Frasier, F., Christensen, S.R., Evans, G.A. \& Dailey, H.A. (1992) A molecular defect in human protoporphyria. Am. J. Hum. Genet., 50, 12031210.

9) Camadro, J.M. \& Labbe, P. (1982) Kinetics studies of ferrochelatase in yeast. Zinc and iron as competing substrates. Biochim. Biophys. Acta, 707, 280-288.

10) Camadro, J.M. \& Labbe, P. (1988) Purification and properties of ferrochelatase from yeast Saccharomyces cerevisiae. Evidence for a precursor form of the protein. $J$. Biol. Chem., 263, 11675-11682.

11) Camadro, J.M., Abraham, N.G. \& Levere, R.D. (1985) Kinetic studies of human liver ferrochelatase. Role of endogenous metals. J. Biol. Chem., 259, 5678-5682.

12) Chretien, S., Dubart, A., Beaupain, D., Raich, N., Grandchamp, B., Rosa, J., Gossens, M. \& Romeo, P.-H. (1988) Alternative transcription and splicing of the human porphobilinogen deaminase gene result either in tissue-specific or in housekeeping expression. Proc. Natl. Acad. Sci. USA, 85, 6-10.

13) Conder, L.H., Woodard, S.I. \& Dailey, H.A. (1991) Multiple mechanisms for the regulation of heme synthesis during erythroid cell differentiation. Possible role for coproporphyrinogen. Biochem. J., 275, 321-326.

14) Cox, T.C., Bawden, M.J., Abraham, N.G., Bottomley, S.S., May, B.K., Baker, E., Chen, L.Z. \& Sutherland, G.R. (1990) Erythroid 5-aminolevulinate synthase is located on the x-chromosome. Am. J. Hum. Genet., 46, 107-11.

15) Cox, T.C., Bawden, M.J., Martin, A. \& May, B. (1991) Human erythroid 5aminolevulinate synthase: Promoter analysis and identification of an iron-responsive element in the mRNA. EMBO J., 10, 1891-1902.

16) Dailey, H.A., Jr. (1977) Purification and characterization of the membrane-bound ferrochelatase from Sprillum itersonii. J. Bacteriol., 132, 302-307.

17) Dailey, H.A. (1982) Purification and characterization of the membrane-bound ferrochelatase from Rhodopseudomonas sphaeroides. J. Biol. Chem., 257, 14714-14718.

18) Dailey, H.A. (1984) Effect of sulfhydryl group modification on the activity of bovine ferrochelatase. J. Biol. Chem., 259, 2711-2715.

19) Dailey, H.A., Jr. \& Lascelles, J. (1974) Ferrochelatase activity in wild-type and mutant strains of Spirillum itersonii. Solubilization with chaotropic reagents. Arch. Biochem. Biophys., 160, 523-529.

20) Dailey, H.A. \& Fleming, J.E. (1983) Bovine ferrochelatase. Kinetic analysis of inhibition by N-methylprotoporphyrin, manganese and heme. J. Biol. Chem., 258, 11453-11459.

21) Dailey, H.A. \& Fleming, J.E. (1986) The role of arginyl residues in porphyrin binding to ferrochelatase. J. Biol. Chem., 261, 7902-7905.

22) Dailey, H.A., Fleming, J.E. \& Harbin, B.M. (1986) Purification and characterization of mammalian and chicken ferrochelatase. Methods Enzymol., 123, 401-408.

23) De Matteis, F., Gibbs, A.H. \& Harvey, C. (1985) Studies on inhibition of ferrochelatase by $\mathrm{N}$-alkylated dicarboxylic porphyrins. Steric factors involved and evidence that the inhibition is reversible. Biochem. J., 226, 537-544. 
24) De Matteis, F., Gibbs, A.H. \& Holley, A.E. (1987) Occurrence and biological properties of N-methylprotoporphyrin. Ann. N.Y. Acad. Sci., 514, 30-40.

25) De Verneuil, H., Grandchamp, B., Foubert, C., Weil, D., N'Guyen, V.C., Gross, M.S., Sassa, S. \& Nordmann, Y. (1984) Assignment of the gene for uroporphyrinogen decarboxylase to human chromosome 1 by somatic cell hybridization and specific enzyme immunoassay. Hum. Genet., 66, 202-205.

26) Deybach, J.C., Da Silva, V., Pasquier, Y. \& Nordmann, Y. (1986) Ferrochelatase in human erythropietic protoporphyria - the first case of a homozygous form of the enzyme deficiency. In: Porphyrins and Porphyrias, edited by Y. Nordmann, Libbey, London, pp. 163-173.

27) Eiberg, H., Mohr, J. \& Staub-Nielsen, L. (1983) Delta-aminolaevulinate dehydrasesyntegency with ABO-AK1-ORM and assignment to chromosome 9. Clin. Genet., 23, $150-154$.

28) Fadigan, A. \& Dailey, H.A. (1987) Inhibition of ferrochelatase during differentiation of murine erythroleukemia cells. Biochem. J., 243, 419-424.

29) Falk, J.E. (1964) Porphyrins and metalloporphyrins their general, physical and coordination chemistry and laboratory methods. In : BBA Library, Vol. 2, Elsevier, Amsterdam.

30) Fearnley, I.M., Finel, M., Skehel, J.M. \& Walker, J.E. (1991) NADH: Ubiquinone oxidoreductase from bovine heart mitochondria. cDNA sequence of the import precursors of the nuclear-encoded $39 \mathrm{kDa}$ and $42 \mathrm{kDa}$ subnits. Biochem. J., 278, 821829.

31) Ferreira, G.C., Andrew, T.L., Karr, S.W. \& Dailey, H.A. (1988) Organization of the terminal two enzymes of heme biosynthetic pathway. Orientation of protoporphyrinogen oxidase and evidence for a membrane complex. J. Biol. Chem., 263, 38353839 .

32) Friend, C., Scher, W., Holland, J.G. \& Sato, T. (1971) Hemoglobin synthesis in murinevirus-induced leukemia cells in vitro: Stimulation of erythroid differentiation by dimethylsulfoxide. Proc. Natl. Acad. Sci. USA, 68, 378-382.

33) Fujita, H., Yamamoto, M., Yamagami, Y., Hayashi, N. \& Sassa, S. (1991a) Erythroleukemia differentiation. Difinitive response of the erythroid-specific and the non-specific $\delta$-aminolevulinate synthase mRNA. J. Biol. Chem., 266, 17494-17502.

34) Fujita, H., Yamamoto, M., Yamagami, Y., Hayashi, N., Bishop, T.R., de Verneuil, H., Yoshinaga, T., Shibahara, S., Morimoto, R. \& Sassa, S. (1991b) Sequential activation of genes of heme pathway enzymes during erythroid differentiation of mouse Friend virus-transformed erythroleukemia cells. Biochim. Biophys. Acta, 1090, 311-316.

35) Fukuda, Y., Fujita, H., Taketani, S. \& Sassa, S. (1993) Dimethylsulfoxide and hemin induce ferrochelatase mRNA by different mechanisms in murine erythroleukemia cells. Br. J. Haematol., 83, 480-483.

36) Goldberg, A., Ashenbrecker, M., Cartwright, G.E. \& Wintrobe, M.M. (1956) Studies on the biosynthesis of heme in vitro by avian erythrocytes. Blood, 11, 821-833.

37) Grandchamp, B., Well, D., Nordmann, Y., Van Cong, N., De Verneuil, H., Fouvert, C. \& Gross, M.S. (1983) Assignment of the human coproporphyrinogen oxidase to chromosome 9. Hum. Genet., 64, 180-183.

38) Grandchamp, B., Beamount, C., de Verneuil, H. \& Nordmann, Y. (1985) Accumulation of porphobilinogen deaminase, uroporphyrinogen decarboxylase, and $\alpha$-and $\beta$-globin mRNAs during differentiation of mouse erythroleukemic cells. Effects of succinylacetone. J. Biol. Chem., 260, 9630-9635.

39) Granick, J.L. \& Sassa, S. (1978) Hemin control of heme biosynthesis in mouse Friend virus-transformed erythroleukemia cells in culture. J. Biol. Chem., 253, 54025406.

40) Hanson, J.W. \& Dailey, H.A. (1984) Purification and characterization of chicken erythrocytes ferrochelatase. Biochem. J., 222, 695-700. 
41) Honeyborne, C.L., Jackson, J.T. \& Jones, O.T.G. (1979) The interaction of mitochondrial ferrochelatase with arange of porphyrin substrates. FEBS Lett., 98, 207210.

42) Igarashi, J., Hayashi, N. \& Kikuchi, G. (1978) Effects of administration of cobalt chloride and cobalt protoporphyrin on $\delta$-aminolevulinate synthase in rat liver. $J$. Biochem., 84, 997-1000.

43) Jones, M.S. \& Jones, O.T.G. (1969) The structural organization of haem synthesis of rat liver mitochondria. Biochem. J., 113, 507-514.

44) Jones, O.T.G. (1968) Ferrochelatase of spinach chloroplasts. Biochem. J., 107, 113119.

45) Karr, S.R. \& Dailey, H.A. (1988) The in vitro and in vivo synthesis of murine ferrochelatase. Biochem. J., 254, 799-803.

46) Kassner, R.J. \& Walchak, H. (1973) Heme formation from Fe (II) and porphyrin in the absence of ferrochelatase activity. Biochim. Biophys. Acta, 304, 294-303.

47) Labbe-Bois, R. (1990) The ferrochelatase from Saccharomyces cerevisiae. Sequence, disruption and expression of its structural gene hem 15. J. Biol. Chem., 265, 7278 $-7283$.

48) Lamolla, A.A. \& Yamane, T. (1974) Zinc protoporphyrin in the erythrocytes of patients with lead intoxication and iron deficiency anemia. Science, 186, 936-938.

49) Lamoril, J., Boulechfar, S., de Verneuil, H., Grandchamp, B., Nordmann, Y. \& Deybach, J.-C. (1991) Human erythropoietic protoporphyria: Two point mutations in the ferrochelatase gene. Biochem. Biophys. Res. Commun., 181, 594-599.

50) Langhof, H., Muller, H. \& Reitschel, I. (1961) Untersuchungen zur familiaren protoporphyrinamischen lichurticaria. Arch. Klin. Exp. Dermatol., 212, 506-518.

51) Mailer, K., Poulson, R., Dolphin, D. \& Hamilton, A.D. (1980) Ferrochelatase: Isolation and purification via affinity chromatography. Biochem. Biophys. Res. Commun., 96, 777-784.

52) Mangus, I.A., Jarret, A., Prankerd. T.A.J. \& Rimington, C. (1961) Erythropoietic protoporphyria: A new porphyria syndrome with solar urticaria due to protoporphyrin-anemia. Lancet, 2, 448-451.

53) Marks, G.S., Allen, D.T., Johnston, C.T., Sutherland, E.P., Nakatsu, K. \& Witney, R.A. (1985) Suicidal destruction of cytochrome P-450 and reduction of ferrochelatase activity by 3, 5-diethoxycarbonyl-1, 4-dihydro-2, 4, 6-trimethyl pyridne and its analogues is chick embryo liver cells. Mol. Pharmacol., 27, 459-465.

54) Matthews-Roth, M.M., Durouin, G.L. \& Duffy, L. (1987) Isolation of human ferrochelatase. Arch. Dermatol., 123, 429-430.

55) Mazanowska, A., Dancewicz, A.M., Malinowska, T. \& Kowalski, E. (1969) Chelation of iron and zinc by protoporphyrin catalyzed by mitochondrial preparations. Eur. J. Biochem., 7, 583-587.

56) Meisler, M., Wanner, L., Eddy, R.E. \& Show, T.B. (1980) The UPS locus encoding uroporphyrinogen-1 synthase is located on human chromosome 11. Biochem. Biophys. Res. Commun., 95, 170-176.

57) Mignotte, V., Wall, L., de Boer, E., Grosveld, F. \& Romeo, P.-H. (1989a) Two tissue-specific factors bind the erythroid promoter of the human porphobilinogen gene. Nucleic Acids Res., 17, 37-54.

58) Mignotte, V., Eleouet, J.F., Raich, N. \& Romeo, P.-H. (1989b) Cis-and trans-acting elements involved in the regulation of erythroid promoter of the human porphobilinogen deaminase gene. Proc. Natl. Acad. Sci. USA, 86, 6548-6552.

59) Miyamoto, K., Nakahigashi, K., Nishimura, K. \& Inokuchi, H. (1991) Isolation and characterization of visible light-sensitive mutants of Escherichia coli K-12. J. Mol. Biol., 219, 393-398.

60) Nakahashi, Y., Taketani, S., Sameshima, Y. \& Tokunaga, R. (1990a) Characterization of ferrochelatase in kidney and erythroleukemia cells. Biochim. Biophys. Acta, 
1037, 321-327.

61) Nakahashi, Y., Taketani, S., Okuda, M., Inoue, K. \& Tokunaga, R. (1990b) Molecular cloning, sequence analysis of cDNA encoding human ferrochelatase. Biochem. Biophys. Res. Commun., 173, 748-755.

62) Nakahashi, Y., Fujita, H., Taketani, S., Ishida, N, Kappas, A. \& Sassa, S. (1992) The molecular defect of ferrochelatase in a patient with erythropoietic protoporphyria. Proc. Natl. Acad. Sci. USA, 89, 281-285.

63) Nakahashi, Y., Miyazaki, H., Kadota, Y., Naitoh, Y., Inoue, K., Yamamoto, M., Hayashi, N. \& Taketani, S. (1993a) The molecular defect in human erythropoietic protoporphyria with fatal liver failure. Hum. Genet., 91, 303-306.

64) Nakahashi, Y., Miyazaki, H., Kadota, Y., Naitoh, Y., Inoue, K., Yamamoto, M., Hayashi, N. \& Taketani, S. (1993b) Human erythropoetic protoporphyria: Identification od a mutation at the splice donor site of intron 7 causing exon 7 skipping of the ferrochelatase gene. Hum. Mol. Genet., 2, 1069-1070.

65) Oritz de Montellano, P.R., Kunze, K.L., Cole, S.P. \& Marks, G.S. (1981) Differential inhibition of hepatic ferrochelatase by the isomers of $\mathrm{N}$-methylprotoporphyrin IX. Biochem. Biophys. Res. Commun., 103, 581-586.

66) Oritz de Montellano, P.R., Costa, A.K., Grab, A., Sutherland, E.P. \& Marks, G.S. (1986) Cytochrome P450 destruction and ferrochelatase inhibition. In: Porphyrins and Porphyrias, edited by Y. Nordmann, Vol. 134, colloque INSERM, John Libbey Eurotext, London, pp. 109-177.

67) Orkin, S.H. (1990) Globin gene regulation and switching: Circa 1990. Cell, 63, 665-672.

68) Porra, R.J. \& Jones, O.T.G. (1963) Studies on ferrochelatase 1. Assay and properties of ferrochelatase from a pig liver mitochondria extract. Biochem. J., 94, 120126.

69) Porra, R.J. \& Ross, B.D. (1965) Haem synthase and cobalt porphyrin synthase in various micro-organisms. Biochem. J., 94, 557-562.

70) Philipson, S., Talbot, D., Fraser, P. \& Grosveld, F. (1990) The $\beta$-globin dominant control region: Hypersensitive site 2. EMBO J., 9, 2159-2169.

71) Riddle, R.D., Yamamoto, M. \& Engel, J.D. (1989) Expression of $\delta$-aminolevulinate synthase in avian cell: Separate genes encode erythroid-specific and basal isozymes. Proc. Natl. Acad. Sci. USA, 86, 792-796.

72) Rossi, E., Costin, K.A. \& Carcia-Webb, P. (1988) Ferrochelatase activity in human lymphocytes, as quantified by a new high-performance liquid-chromatographic method. Clin. Chem., 34, 2481-2485.

73) Rossi, E., Attwood, P.V., Garcia-Webb, P. \& Costin, K.A. (1990) Inhibition of human lymphocyte ferrochelatase activity by hemin. Biochim. Biophys. Acta, 1038, 375-381.

74) Ruth, G.R., Schwartz, S., Stephenson, B., Bathes, F. \& Shave, H. (1978) A new disease of cattle-bovine protoporphyria: Clinical and diagnostic features. Am. Assoc. Vet. Lab. Diag., 21st Ann. Proc. 91-96.

75) Rutherford, T., Thompson, G.G. \& Moore, M.R. (1979) Heme biosynthesis in Friend erythroleukemia cells: Control by ferrochelatase. Proc. Natl. Acad. Sci. USA, 76, 833-836.

76) Sassa, S. (1976) Sequential induction of heme pathway enzymes during erythroid differentiation of mouse Friend leukemia virus-infected cells. J. Exp. Med., 143, 305315.

77) Sassa, S. (1980) Control of heme biosynthesis in erythroid cells. In vivo and in vitro Erythropoiesis. In: The Friend System, edited by G.B. Rossi, Elsevier/NorthHolland Biomedical Press, New York, pp. 219-228.

78) Sassa, S. \& Urabe, A. (1979) Uroporphyrinogen I synthase induction in normal human bone marrow cultures: An early and quantitative response of erythroid 
differentiation. Proc. Natl. Acad. Sci. USA, 76, 5321-5325.

79) Sawada, H., Takeshita, M., Sugita, Y. \& Yoneyama, Y. (1969) Effect of lipid on protoheme ferro-lyase. Biochim. Biophys. Acta, 178, 145-155.

80) Schoenhaut, D.S. \& Curtis, P.J. (1986) Nucleotide sequence of mouse 5aminolevulinic acid synthase cDNA and expression of its gene in hepatic and erythroid tissues. Gene, 48, 55-63.

81) Senjo, M., Ishibashi, T. \& Imai, Y. (1985) Purification and characterization of cytosolic liver protein facilitating heme transport into apocytochrome $b_{5}$ from mitochondria. Evidence for identifying the heme transfer protein as belonging to a group of glutathione S-transferases. J. Biol. Chem., 260, 9191-9196.

82) Simpson, D.M. \& Poulson, R. (1977) Effects of lipids on the activity of ferrochelatase. Biochim. Biophys. Acta, 482, 461-469.

83) Sinclair, P.R., Sinclair, J.F., Bonkowsky, H.L., Gibbs, A.H. \& De Matteis, F. (1982) Formation of cobalt protoporphyrin by chicken hepatocytes in culture. Relationship to decrease of 5-aminolevulinate synthase caused by cobalt. Biochem. Pharmacol., 31, 993-999.

84) Taketani, S. \& Tokunaga, R. (1980) Heme transport from rat liver mitochondria to the microsomes in vitro. Biochem. Biophys. Res. Commun., 92, 1343-1347.

85) Taketani, S. \& Tokunaga, R. (1981) Rat liver ferrochelatase. Purification, properties, and stimulation by fatty acid. J. Biol. Chem., 256, 12748-12753.

86) Taketani, S. \& Tokunaga, R. (1982) Purification and substrate specificity of bovine liver-ferrochelatase. Eur. J. Biochem., 127, 443-447.

87) Taketani, S. \& Tokunaga, R. (1984) Non-enzymatic heme formation in the presence of fatty acids and thiol reductants. Biochim. Biophys. Acta, 798, 226-230.

88) Taketani, S., Tanaka, A. \& Tokunaga, R. (1985) Reconstitution of hemesynthesizing activity from ferric ion and porphyrins, and the effect of lead on the activity. Arch. Biochem. Biophys., 242, 291-296.

89) Taketani, S., Tanaka-Yoshioka, A., Masaki, R., Tashiro, Y. \& Tokunaga, R. (1986) Association of ferrochelatase with Complex I in bovine heart mitochondria. Biochim. Biophys. Acta, 883, 277-283.

90) Taketani, S., Nakahashi, Y., Osumi, T. \& Tokunaga, R. (1990) Molecular cloning, sequencing and expression of mouse ferrochelatase. J. Biol. Chem., 265, 19377-19380.

91) Taketani, S., Inazawa, J., Nakahashi, Y., Abe, T. \& Tokunaga, R. (1992) Structure of the human ferrochelatase gene. Exon/intron gene organization and location of the gene to chromosome 18. Eur. J. Biochem., 205, 217-222.

92) Tokunaga, R. \& Sano, S. (1972) Comparative studies on non-enzymatic and enzymic protoheme formation. Biochim. Biophys. Acta, 264, 263-271.

93) Tutois, S., Montagutali, X., Da Silva, V., Jouault, H., Rouyer-Fessard, P., LeroyViard, K., Guenet, J.-L., Nordmann, Y., Beuzard, Y. \& Deybach, J.-C. (1991) Erythropoietic protoporphyria in the house mouse. A recessive inherited ferrochelatase deficiency with anemia, photosensitivity, and liver disease. J. Clin. Invest., 88, 1730-1736.

94) Whitcome, D.M., Carter, N.P., Alvertson, D.G., Smith, S.J., Rhodes, D.A. \& Cox, T.M. (1991) Assignment of the human ferrochelatase gene (FECH) and a locus for protoporphyria to chromosome 18q22. Genomics, 11, 1152-1154.

95) Yamamoto, M., Hayashi, N. \& Kikuchi, G. (1982) Evidence for the transcriptional inhibition by heme of the synthesis of $\delta$-aminolevulinate synthase in rat liver. Biochem. Biophys. Res. Commun., 105, 985-990.

96) Yamamoto, M., Hayashi, N. \& Kikuchi, G. (1983) Translational inhibiton by heme of the synthesis of hepatic $\delta$-aminolevulinate synthase in a cell-free system. Biochem. Biophys. Res. Commun., 115, 225-231.

97) Yamamoto, M., Yew, N.S., Federspiel, M., Dodgson, J.B., Hayashi, N. \& Engel, J.D. (1985) Isolation of recombinant cDNA encoding chicken erythroid $\delta$ - 
aminolevulinate synthase. Proc. Natl. Acad. Sci. 82, 3702-3706.

98) Yamamoto, M., Kure, S., Engel, J.D. \& Hiraga, K. (1988) Structure, turnover, and heme-mediated suppression of the level of mRNA encoding rat liver $\delta$-aminolevulinate synthase. J. Biol. Chem., 263, 15973-15979.

99) Yamauchi, K., Hayashi, N. \& Kikuchi, G. (1980) Translocation of $\delta$ aminolevulinate synthase from cytosol to the mitochondria, and its regulation by hemin in rat liver. J. Biol. Chem., 255, 1746-1751.

100) Yoneyama, Y., Tamai, A., Yasuda, T. \& Yoshikawa, H. (1965) Iron-chelating enzyme from rat liver. Biochim. Biophys. Acta, 105, 100-105. 